\title{
Evaluating the Social and Development Oriented Performance of Meezan Bank
}

\author{
Shafiullah Jan ${ }^{1}$, Nazim Zaman ${ }^{2}$
}

\begin{abstract}
Islamic banking with its unique feature of profit and loss sharing (PLS) is promoted under the Islamic economic paradigm with a promise to internationalise the aspiration of Muslim around the globe to be authentic and true to their tradition. Consequently, provide the capital base to achieve economic development in the Muslim world with the overall objective of human well being and social justice according to maqâsid al Shari'ah. Our study of Meezan bank in Pakistan shows that only a negligible portion of financing activities of the bank is strictly PLS based. Furthermore, financing across different industries are contributing to financialisation of the economy rather than real economy.
\end{abstract}

\section{Introduction}

The mid-twentieth century saw the emergence of a literature characterised as Islamic economics with a goal to transform the existing political, legal, social and economic institutions of Muslim societies into institutions that conforms to Islamic scriptures and traditions (Hooker et al., 2004; Kuran, 1995). Islamic economics was viewed as paradigm shift and a radical alternative to conventional neoclassical views for its concern for justice, equity, poverty and its multidimensional conception of human development. Thus Islamic banking and finance, operational tools of Islamic economics received considerable boost at both the theoretical and practical levels in order to finance economic activities in an Islamic framework. Since 1980 Islamic finance became internationalised reflecting the aspiration of Muslims to be authentic and true to their traditions, while at the same time remaining part of the ongoing and rapid changes that are occurring around the world(Hooker, et al., 2004). According to Asutay (2007a), Islamic banks and Islamic financial institutions were promoted to provide the capital base through which economic development in the Muslim world can be achieved, thus providing the role of economic development with the objective of human well being and social justice according the maqâsid al Shari'ah.

1 Lecturer IMSciences PhD Scholar Durham Centre for Islamic Economics and Finance School of Government and International Affairs Durham University, UK, Email:shafiullah.jan@durham.ac.uk

2 Lecturer Durham Centre for Islamic Economics and Finance School of Government and International Affairs Durham University, UK, Email: n.a.zaman@durham.ac.uk

Tel: +44 (0)7817783385 
Since the establishment of Dubai Islamic Bank in 1975, first private Islamic bank designed to achieve profit maximization on commercial basis, the Islamic banks and Islamic financial institutions (IFI) have grown at considerable pace with a presence in more than 75 Muslim and non-Muslim countries and total financial assets now estimated to exceed \$1 trillion (Akhtar et al., 2008). Islamic finance and banking are estimated to grow annually on average 15-20 percent, and among the fastest growing financial segments in the international financial system with number of Islamic banking institutions worldwide, including conventional banks that are offering Islamic banking services, has doubled to more than 300 (Akhtar, et al., 2008). However, according to Asutay (2007a), the close study of financing of Islamic financial institutions shows that the social dimension is only limited with their zakah and other charitable activities which does not imply any systematic economic development and social justice action.

The basic concern of Islam is the welfare of human, thus, the material world is but a way to Allah and not a diversion from Him. According to majority of fuqahâ (Muslim jurists), the welfare of the people and their relief from hardship are the basic objectives of Shari'ah (Chapra, 1985). Thus in such context, the aim and objective of Islamic banking and finance in Islamic economics paradigm is to organize the resources of earth on the basis of cooperation and participation by removing factors as inequality, monopolies, unfair distribution beside others to achieve social justice and economic development and ultimately helping human beings to achieve falah or felicity in this world and in the Akhirah.

In this paper, the role and social contribution of Meezan bank, a pioneer Islamic bank in Pakistan, is used to evaluate its performance as a real contributor to economic development. The paper is organised as follows: Section 2 provides a theory of Islamic banking and finance. Section 3 provides a survey of what is going on under that banner, highlighting current practices in the Islamic financial industry. Section 4 analyses the financial composition of Meezan Bank and its sectorial distribution across different industries. Section 5 provides a discussion and concludes the paper.

\section{Theory of Islamic Banking and Finance}

The basic tenets and principles of Islamic banking and finance are built upon the Qur'anic prohibition of Riba, which literally means increase, addition, expansion or growth (Chapra, 1985). Riba is categorically and indisputably prohibited in the Qur'an: 
Those who devour Riba will not stand except as stand one whom the Evil one by his touch hath driven to madness. That is because they say: "Trade is like Riba," but Allah has permitted trade and forbidden Riba. Those who after receiving direction from their Lord, desist, shall be pardoned for the past; their case is for Allah (to judge); but those who repeat (The offence) are companions of the Fire: They will abide therein (for ever).

Allah will deprive Riba of all blessing, but will give increase for deeds of charity: For He loves not creatures ungrateful and wicked [Al-Baqarah (2):275276].

O ye who believe! Devour not Riba, doubled and multiplied; but fear Allah. That ye may (really) prosper [Al Imran (3):130].

However, in Shari'ah, Riba is used in two senses, Riba al-nasi'ah and Riba al-fadl(Chapra, 1985)

\subsection{Riba Al-Nasi'ah}

Riba al-nasi'ah refers to interest on loan. In Qur'an, verse [2:279] clearly, defines Riba al-nasi'ah as an increase in a principal sum charged on loans which clearly order Muslim to abandon Riba otherwise to expect a war from Allah and His messenger.

\subsection{Riba Al-Fadl}

Riba al-fadl prohibits trading goods of the same genus and kind in different quantities. The Prophet Muhammad (PBUH) ahadith (Traditions) particularly discuss the nature of Riba al-fadl. Riba al-fadl is an unlawful excess in the exchange of two counter-values where the excess is measurable through weight or measure. The most famous hadith about Riba al-fadl is referred to as 'six commodities hadith'. According to Prophet Muhammad (PBUH):

Gold for gold, silver for silver, wheat for wheat, barley for barley, dates for dates, and salt for salt should be exchanged like for like, equal for equal, and hand-to-hand(on the spot). If the types of the exchanged commodities are different, then sell them as you wish, if they are exchanged on the basis of a hand-to-hand transaction [Muslim, Sahih, V: 44].

The exact nature of prohibition on Riba is controversial, but there is a widespread agreement that the ban on Riba implies a ban on interest (Nyazee, 1995). The prohibition of Riba in Islamic finance means that no interest can be charged or received which is contrary to conventional finance, where interest is considered an important to reflect growth, economic circumstances and the availability of capital (Schoon, 2009). 
Other prohibitions related Islamic banking and finance are Gharar and Maysir. Gharar is generally translated uncertainty regarding the asset, price or delivery data in exchange contract. Therefore, all acts and conditions, the full implications of which are not clearly known to the parties at the time of exchange contracts are considered Gharar (El-Gamal, 2000; Munawar, 2007). For example, Gharar is said to exist in derivative transactions, such as forward, futures and options, in short selling, and in speculations. While Maysir is when there is a possibility of total loss to one party in the contract and is associated with games of chance or gambling (Visser, 2009). Finally, the restrictions on particular "sin sectors" are based on the Islamic prohibitions on certain commodities such as alcohol, drugs, and pork. Shari'ah laws forbid Muslims from consuming these forbidden commodities and, therefore, neither individuals nor institutions are permitted to trade in or finance enterprises that deal in such commodities (Lewis et al., 2001).

In any society, social justice requires a set of rules or moral values, which everyone accepts and faithfully complies with. The first condition for social justice in financial realm requires that both financier and entrepreneur share the profit as well as the losses, which is one of the basic principles Islamic finance is based on that is 'no risk, no gain'. This principle introduces greater discipline in the financial system by motivating the financial institution to access their risk more carefully and monitors the use of funds by the borrower avoiding the risk of losses. The Islamic financial system does not allow the creation of debt through direct lending and borrowing (Siddiqi, 2005). It rather requires the creation of debt through the sale or lease of real assets by means of its sales- and lease-based modes of financing. The purpose is to enable an individual or firm to buy now the urgently needed real goods and services in conformity with their ability to make the payment later.

Broadly speaking, activities based on participatory mechanism have been based on two principles in Islam banking: the profit and loss sharing (PLS) principle and non profit and loss sharing (Figure 1)

Islamic banking Contracts(source: Iqbal et al., 1987)

\subsection{Profit and loss sharing schemes}

\subsubsection{Mudarabah}

Mudarabah financing is a special kind of partnership where banks provide capital and the entrepreneur contributes efforts and exercise complete control over the business entity. The bank, which provides capital, is called "rabb-ulmal" and the entrepreneur providing management skills is called "mudarib". It is necessary for the validity of Mudarabah that the bank and entrepreneur agree right at the beginning on a definite proportion of the actual profit to which each one of them is entitle. In case of a loss, the bank earns no return or a negative return on its investment. 
Figure 1

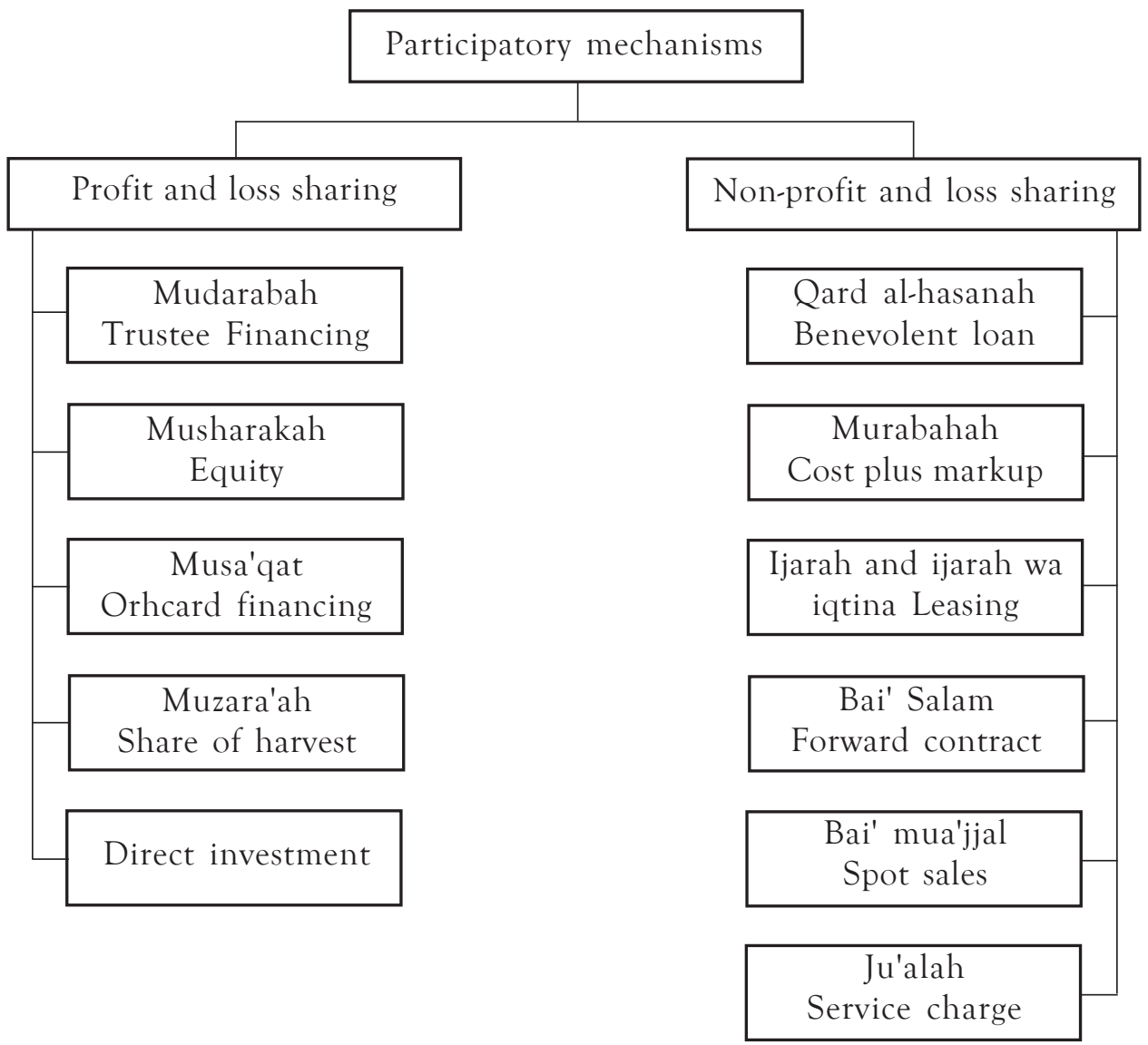

\subsubsection{Musharakah}

Musharakah financing is type of financing where bank and entrepreneur both supply the capital and share management of the entity or project. In case of a loss, both parties share the losses in proportion to the contribution of the capital, which could be exceeded than initial investments as its unlimited liability, while profits proportions are negotiated freely.

In general, Mudarabah financing may be similar to limited partnership while Musharakah financing is closed to a traditional equity stake with rights of control with unlimited liabilities.

\subsubsection{Musqat}

Musqat is a type of Musharakah contract. In this case, the bank provides farmers orchards, gardens or trees, possessed by the bank for harvesting on crop sharing. 


\subsubsection{Imuzara'ah}

Imuzara'ah is a type of Mudarabah contract between an owner of a piece of agricultural land, and a farmer for farming it in return of a percentage of its crop. In this case, Islamic bank provides farmers the land, possessed by the bank for cultivation on crop sharing.

\subsubsection{Direct Investment}

Direct investment like other western banks allows banks to provide part of capital of a new joint stock company and to purchase shares of existing stock companies. However, Islamic banks cannot invest in the production of any good or service that might even appear contrary to the ethical and moral values of Islam.

\subsection{Non-profit and loss sharing schemes}

\subsubsection{Qard al hasanah}

Qard al hasanah, are zero return loans that that Qur'an encourages Muslim to make to those who need them. Banks and financial institutions are permitted to charge the borrower a service charge to cover administrative and transaction costs of handling the loan as long as such costs are not related to the maturity or amount of loan.

\subsubsection{Murabahah}

Murabahah is a sale contract where the seller explicitly mentions the cost of the sold commodity he or she has incurred and sells it to another person by adding some profit or mark-up thereon(Usmani, 2002). In Islamic bank, Murabahah is a mode of financing, where the entrepreneur requests the bank to purchase the asset from the third party against payment. Immediately, the bank sells the asset to the entrepreneur at cost plus an agreed fixed profit margin. Payment is made in the future in lump sum or in installments. Ownership of the asset still resides with the bank till all the payments are made. According to Retired Justice Taqi Usmani (2002), originally Murabahah was not a mode of finance, and it is only devised to escape interest and not the ideal instrument for carrying out the real economic objectives of Islam. Thus should be avoided and restricted to only those cases where Mudarabah or Musharakah are not practicable.

\subsubsection{Ijarah}

Ijarah financing is a form of leasing which involves a contract where the bank buys and then leases an item to the entrepreneur for a specified rental 
over a specific period. The duration of the lease, as well as the basis for rental, are set and agreed in advance. Bank retains ownership of the item throughout the arrangement and takes back the item at the end. In Ijarah contract, the lessee or "Ameen" is entitled to use the asset only for the purpose specified in the agreement in return for the rental agreed upon. Thus, the lessee is only accountable for loss to the asset due to his or her negligence otherwise not liable for loss caused by factors beyond his or her control (Ayub, 2007). In Ijarah-wa-iqtina, the ownership is gradually transferred to the entrepreneur in a rent as a rent to own contract. In this arrangement, the customer simultaneously enters into two contracts, Ijarah agreement, and the future purchase agreement and pays the purchase price in installment along the rent.

\subsubsection{Bai muajjall}

Bai muajjall, allows deferred payments on products. It is like Murabahah mode of financing with the exception that the sale under bai muajjal is made on basis rather than cash. The bank under bai muajjal follows the same conditions as Murabahah except : the bank transfer the possession of goods to the client before the payment is made to the bank and the bank asks for collateral securities from the client to cover the sale price of the goods. The bank can sell the collateral to realise the amount of sale price in case of default by the client (Alam, 2003).

\subsubsection{Bai Salam}

Bai Salam, also known as bai salaf is similar to forward contract, which permits advance sale contracts. In this contractual sale, the advanced payment is made by the buyer to the seller for the deferred supply of goods at a

specified date pre-determined in the contract. In Islamic Finance, the sale of the commodity which is not in the possession of a seller is not permitted. But the practice of bai Salam has been legalized as an exceptional case on the ground of necessity. In banking system, bai Salam allows the entrepreneur to sell some specified goods to a bank at a price determined and paid at the time of contract, with delivery of the goods in the future (Chong et al., 2009)

\subsubsection{Ju'alah}

Ju'alah is the service charge that usually occurs during transaction of various services provided by the Islamic banks to clients. This mode facilitate consultative, fund placement and trust activities (Khan et al., 1990). 


\section{The role of Islamic Banks and Financial Institutions (IBFI) in an Economy}

While the injunction against Riba in all forms are indeed the cornerstone of Islamic finance however, according to Islamic Moral Economy (IME), the role of Islamic banking and financial institution is not just limited to elimination of Riba, since different legal devices (hiyal) can be used to circumvent the prohibition on Riba (for detail: El-Gamal, 2005; Vogel et al., 1998). According to Asutay (2011), beside elimination of Riba, gharar and maysir, the following should be the functions of Islamic finance according to IME.

- Bank to serve communities rather markets

- Responsible finance to build systematic checks on financial providers and restrain consumer indebtedness,

- $\quad$ Ethical investment and corporate social responsibility initiatives

Thus to conclude IBF institutions must serve social interest, such as microfinance to eliminate poverty by building the capacity for poor, in establishin its financial optimality whereby producing an ethical and social solution to developing the Muslim and developing countries; and hence the importance of social optimality as opposed to financial optimality.

Even though the principles of Shari'ah provide a complete guidance for banking system to bring stability in the economy, there are three stylized facts of Islamic Banks operation consistently reported and stand out in sharp contrast to those principles.

The first and the most critical of these facts is the composition of financing techniques in the overall lending operations of Islamic banks. The main thrust of Islamic financial contract is on the principle of profit and loss sharing. Islam also allows mark-up based instruments. Mark-up can imply a fixed return on investment for the bank. Although mark-up instruments are widely used, disagreement over their permissibility in Islam is regularly cited in the legal literature. Scholars thus have taken the position that mark-up techniques, while permissible, should still be avoided or restricted (Khan et al., 1987; Siddiqi, 1983).

Hasan (2005) provides three years data to show the use of various modes of Islamic finance in Malaysian Islamic banks, according to which the percentage shares of Musharakah declined from 1.4\% in 2000 to $0.7 \%$ in 2001 and further to $0.5 \%$ in 2003 while the major Islamic financing modes are in the form of bay bi thaman al-ajil (deferred payment sale) and Ijarah thumma al-bay 
(hire purchase) with $47.4 \%$ and $27.9 \%$ respectively in 2003 . Furthermore, according to Iqbal and Molyneux (2005) the percentage weight of Musharakah and Mudarabah in ten sample Islamic banks total activities for the period of 1994-1996 was only 7\% each, while Murabahah claimed 70\% of total financing. Similarly, Samad, Gardner et al.(2005) using data from annual reports 2002 of Islamic Bank of Bahrain and the Bank Islam Malaysia (Berhad) show that the average Mudarabah is $5 \%$ of total financing, and the average Musharakah is less than 3\%. Whereas combined average of Mudarabah and Musharakah for the two Islamic banks is less than $4 \%$ of the total finance and advances. Furthermore the average Qard alhasna is about 4\%, while Istisna does not yet exist in practice. On the other side, Murabahah is the most favourite and dominate mode of financing. The average use of Murabahah is over $54 \%$ but when the bay' bi al-thaman al-ajil is added to the Murabahah, the percentage of total financing is shown to be $82.68 \%$. Rajesh and Tarik (2000) plot the data from the flow of new financing for Iran, Egypt's Faisal Islamic Bank FIBE, Jordan Islamic Bank (JIB) and Bank of Islam Malaysia. The authors show that markup financing has consistently comprised more than $50 \%$ of flows of new financing for all these banks. Kuran (1995) also supported the argument that less than $5 \%$ of the assets of Islamic banks consist of loans based on genuine profit and loss sharing schemes. The same results are also supported by data from other Islamic banks. Kazarian (1993) in his study of Egypt's Faisal Islamic Bank(FIBE) finds that out of 35\%bof the total assets used for financing domestic projects, $90 \%$ of the financing is mark-up financing and the bank also adopted the policy of restricting PLS financing to $2 \%$ of total domestic financing. These evidences indicate that bulk of financing operations of Islamic banks do not conform to the principle of profit-and-loss sharing (e.g., equity contracts). Instead, most of the financing is based on the mark-up principle. Yousaf (2004) refers to the strong and consistent tendency of Islamic banks to utilise debt like financing instruments as the "Murabahah syndrome". Thus indicating that Islamic banks and finance have deviated from the aspirational stand of Islamic economics (Asutay, 2007a).

The second and third facts regarding the practices of Islamic banks are concerned with the term structure and sectorial distribution of finance. Islamic economists (for example,Chapra, 1992; Siddiqi, 1983) have argued that Islamic banks can promote growth in Islamic countries by providing long-term financing to growth sectors of the economy. Entrepreneurial projects in Agricultural and industry will have greater implication for growth. According to Iqbal and Molyneux (2005), with the exception of Istisna all other trade based modes of financing are suitable only for short term financing. Aggrawal and 
Yousaf (2000) utilizing the data of Metwally (1992) of twenty two Islamic banks and investment banks find that on average $56.7 \%$ of total financing were for maturities of less than a year. In fact, Islamic banks out of their total assets kept $26.6 \%$ as a deposit with other banks and central bank. In another study Kazarian (1993) reports that for Faisal Islamic Bank of Egypt the ratio of long-term financing to all financings is a third of that for other Egyptian commercial banks and for the Islamic Bank for International Development (IBID) the ratios of long-term financing to all financings is half that other investment banks. Kazarian also finds that commercial banks in Egypt have extended 37\% of their financing to industry and agricultural in 1979-90 compare to FIBE which allocated only $10 \%$. IBID allocated $11 \%$ to agriculture and industry compared to $17 \%$ for Egypt's other investment banks. Saffari (1995) in his unpublished work, using the data from Iran also finds that banks failed to meet target levels of financings to industry, construction and agriculture imposed by the central bank.

Even though Musharakah and Mudarabah are core pillars of Islamic banking system, the data about financing decision of Islamic banks clearly shows that these modes of financing have limited role in the financial compositions of Islamic banks compare to the other modes of financing. However, the data about such practices is only up till 2005, therefore, due to lack of availability of latest data to provide a better picture of different modes of financing in Islamic banking, it cannot be concluded as a fact that such practices are still followed by Islamic banks.

In order to examine the current practices regarding how funds are employed for financing on the asset side of Islamic Bank, we have selected Meezan bank of Pakistan due to availability of their data. The data about modes of financing by the Islamic banks is selected from its annual reports from 2006 till 2010.

In our analysis, two types of data are collected, first, how Meezan bank has utilised its funds on the assets side and secondly, how these funds are distributed over the industries. The primary goal of the analysis is to provide detailed picture of how much Islamic bank adhere to the true essence of IME, thus using majority of their funds according to the Musharakah and Mudarabah modes of financing. Second, how these funds are distributed over the industry to analyse the role of Islamic banking and finance in economic development of Pakistan. Such an analysis renders valuable information to evaluate the social and development contributions of Islamic banks on the other hands, and demonstrates their impact on value added and the capacity building on the 
other hand. Analysing the financing strategies of these institutions also enables us to conclude whether Islamic banks are contributing to financialisation of the economy or whether they are embedded in the real economy through financing economic activity.

\section{Analyses}

\subsection{Financial composition of Meezan Bank's financial assets}

Meezan Bank is the first and largest Islamic bank in Pakistan. The data presented in Table 1 shows the importance of the various Islamic financing modes on the asset side of the balance sheet, obtained from annual reports of Meezan bank covering from 2006 till 2010. As it is shown, total Islamic financing and advances by the Meezan Bank from 2006 till 2010 are, 58.21\%, $51.47 \%, 46.63 \%, 35.58 \%$ and $35.02 \%$ of total assets respectively, which however are on the decreasing trend. When the composition of total Islamic finance in Table 1 is examined, it shows that Meezan bank has not done any financing through Mudarabah, while Musharakah plays virtually no role in the bank compare to other modes of financing, which is less than $0.5 \%$ throughout five years of data. The another form of Musharakah deployed by Meezan bank is Diminishing Musharakah, a type of partnership where one partner purchases the other partner's share gradually, has been on increasing trend, constituted $27.18 \%$ in 2010 compare to $13.98 \%$ in 2006 . The majority of diminishing Musharakah contracts is used to finance housing sector. Even though, Musharakah and Mudarabah modes of financing are the most significant in principle and are considered the core of Islamic financing, in practice, they constitute insignificant and only satisfactory when combined with diminishing Musharakah concentrated only in housing sector.

Murabahah on the other side, constitute more than $60 \%$ of total financing in 2006, which has decreased to around 42\% in 2010. Ijarah is another mode of Islamic financing, which means selling the benefit of use or service for a fixed price or wage over fixed time. It has decreased from over $23 \%$ in 2006 to just over 13\% in 2010. While on other hand, Bank introduced Istisna to finance construction of buildings, residential towers, villas and related products, and manufacturing of aircrafts, ships, machines and equipment, and others, in 2007. Istisna has increased to over $11 \%$ of total financing compare to $0.68 \%$ in 2007 . This also signifies shift in the financing of sectors, as the construction industry has been an essential sector financed through Islamic banking in Pakistan. This is also verified by the diminishing Musharakah mostly

in housing schemes discussed above. Salam (forward financing) is just above 
$1 \%$ which is the same throughout the years. Another Islamic mode of financing, utilised by Meezan bank is Tijarah or trade financing. Even though, there is no trade financing in 2006 annual report, it has, however, increased from none to $2.53 \%$ in 2010 . Tijarah financing is working capital financing solution, which is Shari'ah complaint and provides opportunity to both corporate and small and medium enterprises to meet their working capital requirements and enjoy the benefits of cash sales.

Qard alhasna financing, another cornerstone of IME and Islamic finance for helping poor and needy, is an interest free loan encouraged in Qur'an and Sunnah. The size of this mode of financing to total financing in Meezan bank is $0.01 \%$ in both 2009 and 2010 . The amount is mostly dispersed for Hajj and Umrah. Furthermore, there is no such provision in the form of interest free loans in 2006, 2007 and 2008. The bank provides interest free loan under Islamic financing however, this loan is only issued to the staff. Furthermore, Zakat, compulsory religious alms giving and one of the five pillars of Islam, is collected on deposit accounts but there is no information provided in the annual reports. However, Meezan bank distributed charity of over 106 millions

Table 1: Allocation of Funds under Finance and Advances - Meezan Bank

\begin{tabular}{|l|c|c|c|c|c|}
\hline $\begin{array}{l}\text { Modes of } \\
\text { Financing }\end{array}$ & 2006 & 2007 & 2008 & 2009 & 2010 \\
\hline Murabahah & $60.17 \%$ & $59.10 \%$ & $46.81 \%$ & $47.14 \%$ & $41.88 \%$ \\
\hline $\begin{array}{l}\text { Diminishing } \\
\text { Musharakah } \\
\text { (housing and } \\
\text { others) }\end{array}$ & $13.98 \%$ & $14.92 \%$ & $23.35 \%$ & $22.57 \%$ & $27.18 \%$ \\
\hline Musharakah & $0.48 \%$ & $0.23 \%$ & $0.20 \%$ & $0.17 \%$ & $0.12 \%$ \\
\hline Ijarah & $23.40 \%$ & $22.01 \%$ & $23.38 \%$ & $17.18 \%$ & $13.20 \%$ \\
\hline Istisna & & $0.68 \%$ & $3.93 \%$ & $7.98 \%$ & $11.31 \%$ \\
\hline Salam & $1.34 \%$ & $1.87 \%$ & $1.19 \%$ & $1.29 \%$ & $1.28 \%$ \\
\hline $\begin{array}{l}\text { Tijarah or } \\
\text { trade } \\
\text { financing }\end{array}$ & - & - & $0.02 \%$ & $1.42 \%$ & $2.53 \%$ \\
\hline Qard alhasan & - & - & - & $0.01 \%$ & $0.01 \%$ \\
\hline Others & $0.63 \%$ & $1.20 \%$ & $1.13 \%$ & $2.23 \%$ & $2.49 \%$ \\
\hline Financing & $27,031,016$ & $34,576,339$ & $39,768,481$ & $44,188,066$ & $54,195,163$ \\
\hline Total Assets & $46,438,623$ & $67,178,559$ & $85,276,070$ & $124,181,734$ & $154,752,425$ \\
\hline
\end{tabular}


(in rupees) which accounts about $6.4 \%$ of total profit in 2010 . The percentages of charity with respect to net profit in 2009 till 2006 were 5\%, 5.84\%, $3.87 \%$ and $1.57 \%$ respectively. Overall, Meezan Bank has adopted various modes of Islamic financing on the asset side of balance sheet, however, more than $75 \%$ of these Islamic financing are concentrated in instruments other than Musharakah and Mudarabah.

\subsection{Industry sector analysis of the Meezan Banks' financial assets}

For our analysis, data is obtained from the annual report of Meezan bank from 2006 till 2010 to analyze the distribution of financial assets over different industry sectors to evaluate the role of the bank in the development and to conclude whether Meezan bank is contributing to financialisation of the economy or it is part of real economy through their financing activities.

The data provided in Table 2 shows the sectoral distribution of financing of Meezan bank. As it can be seen, the bank has distributed the financing activities across many sectors. Agriculture, forestry, hunting and fishing has only received $1 \%$ of total financing 2006 . Being an agricultural country, Pakistan economy is depended on the growth of agriculture sectors, however, the contribution of the bank to finance agricultural sector is insignificant. The percentage of financing in agriculture, forestry, hunting and fishing decreased to less than one percent from 2007 till 2010. The majority of finances are received by the textile industry, which is also the back bone of Pakistani economy. Textile received 35\% of total financing in 2006, 31\% in 2007, 26\% in $2008,30 \%$ in 2009 and $33 \%$ in 2010 . Foot wears and leather garments received $6 \%$ of total financing in 2006, which decreased to 3\% in 2007 and 2008 and 2\% in 2009 and 2010. Pakistani economy is facing shortage of electric power, which is severely damaging other power dependent sectors, however, the bank has only expanded $1 \%$ of total financing in 2006, which has eventually increased to $4 \%$ in 2010 , even though still below par compare to the demand and necessity. Chemical and pharmaceutical industry, with high prospects of growth has received $4 \%$ of total financing 2006, reaching to $7 \%$ in 2010. Construction industry received around 2 to $3 \%$ of total financing from 2006 till 2010. Automobile and transportation, sugar and wholesale and retail trade have received 2 to $7 \%$ of total financing from 2006 till 2010. Service sector remained at 2\% of total financing from 2007 till 2010. Individuals received $21 \%$ of total financing in 2006 , and 2007 , decreasing to $11 \%$ in 2010. 
Table 2: Sectoral distribution of financing activities - Meezan Bank

\begin{tabular}{|c|c|c|c|c|c|}
\hline Sectoral Distribution & 2006 & 2007 & 2008 & 2009 & 2010 \\
\hline $\begin{array}{l}\text { Agriculture, forestry, } \\
\text { hunting and fishing }\end{array}$ & $1 \%$ & $0 \%$ & $0 \%$ & $0 \%$ & $0 \%$ \\
\hline Textile & $35 \%$ & $31 \%$ & $26 \%$ & $30 \%$ & $33 \%$ \\
\hline $\begin{array}{l}\text { Automobiles and } \\
\text { transportation }\end{array}$ & $5 \%$ & $4 \%$ & $2 \%$ & $2 \%$ & $2 \%$ \\
\hline Financial institutions & $0 \%$ & - & $0 \%$ & - & - \\
\hline $\begin{array}{l}\text { Electronics and } \\
\text { electrical appliances }\end{array}$ & $0 \%$ & $2 \%$ & $2 \%$ & $1 \%$ & $4 \%$ \\
\hline Construction & $2 \%$ & $3 \%$ & $3 \%$ & $2 \%$ & $1 \%$ \\
\hline $\begin{array}{l}\text { Power (electricity), } \\
\text { gas and water }\end{array}$ & $1 \%$ & $2 \%$ & $5 \%$ & $3 \%$ & $4 \%$ \\
\hline Exports / imports & $2 \%$ & $3 \%$ & $5 \%$ & $3 \%$ & $2 \%$ \\
\hline $\begin{array}{l}\text { Transport, storage } \\
\text { and communication }\end{array}$ & $1 \%$ & $1 \%$ & $0 \%$ & $0 \%$ & $3 \%$ \\
\hline $\begin{array}{l}\text { Chemicals and } \\
\text { pharmaceuticals }\end{array}$ & $4 \%$ & $8 \%$ & $7 \%$ & $8 \%$ & $7 \%$ \\
\hline Sugar & $3 \%$ & $2 \%$ & $2 \%$ & $3 \%$ & $2 \%$ \\
\hline $\begin{array}{l}\text { Footwear and leather } \\
\text { garments }\end{array}$ & $6 \%$ & $3 \%$ & $3 \%$ & $2 \%$ & $2 \%$ \\
\hline $\begin{array}{l}\text { Wholesale and retail } \\
\text { trade }\end{array}$ & $2 \%$ & $7 \%$ & $12 \%$ & $6 \%$ & $6 \%$ \\
\hline Cement & $0 \%$ & $2 \%$ & $5 \%$ & $4 \%$ & $7 \%$ \\
\hline Services & $0 \%$ & $2 \%$ & $2 \%$ & $2 \%$ & $2 \%$ \\
\hline Individuals & $21 \%$ & $21 \%$ & $19 \%$ & $14 \%$ & $11 \%$ \\
\hline Others & $16 \%$ & $10 \%$ & $7 \%$ & $20 \%$ & $14 \%$ \\
\hline
\end{tabular}

\section{Discussion and Conclusion}

In the presence of thin financial market and underdeveloped institution, Islamic banks will provide Muslims with permissible analogues of conventional financial services and products that are generally consider impermissible in Islamic jurisdiction. As noted by El-Gamal (2005) in his study that Islamic products are the re-engineered version of conventional financial products approved by the jurists who are on Islamic financial institutions payroll. El-Gamal calls these products a Shari'ah arbitrage. He concludes that conventional banks 
use its regular funds to finance the purchase of assets in so called Islamic manner, through Murabahah or Ijarah finance.

Furthermore, recent developments of debt-like financing in Islamic finance for example tawarruq and iniah are enthusiastically welcomed in the market as evident in Malaysia where sale of debt is allowed. Similarly GCC countries while disallowed sale of debt, have permitted inclusion of small component of account receivable in a larger package of securities (Siddiqi, 2007). According to Siddiqi such development of debt-like instruments are due to Juristic discourse with primarily concern for the contractual aspects of these instruments. Nevertheless, Asutay (2007a) argues that such realities of financial markets where economic incentives are prioritised over religious behaviour norms have consequentially shifted the Islamic finance to become part of the international financial system, "in which it is recognised as heterogenoisation of financial products deprived of their value system imposed by utopian Islamic economics". Thus has failed to produce the economic development promised by Islamic Moral Economic and promoted by the Islamic development process.

After close analysis of current trends discussed above, Islamic finance in reality is far away from fulfilling the economic development's objectives of the development process. The objective of current practices of Islamic finance and banking is thus financialization as opposed to financing according to IME's expectations. The aim of the institutions according to Islamic development process is to promote the welfare of human beings. Therefore, in such context, IBFI are to help to further promote and utilise the goals of the IME, ultimately the welfare of human beings. Even though, Islamic banks are based on western banking model with ultimate goal of profit making, however, such goals should be in line with the overall goals of IME by promoting Islamic norms and values as well as protecting the needs of Islamic society as a whole. Unfortunately, Islamic finance according to Dar (2002) is seen an "elitist phenomenon without much grassroots level appeal", thus seen as another tool of injustice that only promote the agenda of self interest, in other words, capitalism.

However, with all criticism, currently there is no alternative available beside IBFI to gather resources from mass and channelize those resources to promote economic development according to Shari'ah. The IBFI though lack on contribution and promotion of IME objectives in complete spirit but legally cover contractual aspects according to Shari'ah. There is more for the IBFI to adopt from IME to help promote the economic development than the legal requirement of halal or haram. 


\section{References}

Aggarwal, R. K., \& Yousef, T. (2000). Islamic Banks and Investment Financing. Journal of Money, Credit and Banking, 32(1), 93-120.

Akhtar, S., Aziz, Z. A., Hefner, R. W., Thani, N. N., Venardos, A., Vogel, F. E., \& Warde, I. (2008). Understanding Islamic Finance: Local Innovation and Global Integration. Asia Policy, 6.

Alam, M. N. (2003). Institutionalization and Promotion of Saving Habits Through Bai-Muajjal Mode of Financing (A unique means of mobilizing rural savings towards productive sources). Managerial finance 29, 3-22.

Asutay, M. (2007a). Conceptualisation of the second best solution in overcoming the social failure of Islamic banking and finance: examining the overpowering of Homoislamicus by Homoeconomicus. IIUM Journal in Economics and Management, 15(2), 167-195.

Asutay, M. (2011). Islamic microfinance: An alternative development financing method. Paper presented at the Microfinance and Its Dual Objective: Financial-Social Inclusion and Sustainable Business Development, IE Business School, Madrid.

Ayub, M. (2007). Understanding Islamic finance. Hoboken, NJ: John Wiley \& Sons.

Chapra, M. U. (1985). Towards a just monetary system: a discussion of money, banking, and monetary policy in the light of Islamic teachings. Leicester, UK: Islamic Foundation.

Chapra, M. U. (1992). Islam and the economic challenge. Leicester, UK; Herndon, VA: Islamic Foundation ; International Institute of Islamic Thought.

Chong, B. S., \& Liu, M.-H. (2009). Islamic banking: Interest-free or interest-based? PacificBasin finance journal., 17(1), 125.

Dar, H. A. (2002). Islamic House Financing in the United Kingdom: Problems, Challenges and Prospects. Review of Islamic Economics(12), 47-72.

El-Gamal, M. A. (2000). A basic guide to contemporary Islamic banking and finance. Houston, TX: Rice University.

El-Gamal, M. A. (2005). Limits and Dangers of Shari'a Arbitrage. In S. N. Ali (Ed.), Islamic finance: current legal and regulatory issues. Cambridge, Mass.: Islamic Finance Project, Islamic Studies Program, Harvard Law School.

Hasan, Z. (2005). Islamic banking at the crossroads: theory versus practice. In M. Iqbal \& R. Wilson (Eds.), Islamic Perspectives on Wealth Creation. Edinburgh: Edinburgh University Press.

Hooker, V. M., Saikal, A., \& Institute of Southeast Asian, S. (2004). Islamic perspectives on the new millennium. Singapore: Institute of Southeast Asian Studies.

Iqbal, M., \& Molyneux, P. (2005). Thirty years of Islamic banking: history, performance, and prospects. Houndmills; New York: Palgrave Macmillan. 
Iqbal, Z., \& Mirakhor, A. (1987). Islamic banking. Washington, D.C.: International Monetary Fund.

Kazarian, E. G. (1993). Islamic versus traditional banking: financial innovations in Egypt. Boulder: Westview Press.

Khan, M. S., \& Mirakhor, A. (1987). Theoretical studies in Islamic banking and finance. Houston, Tex.: Institute for Research and Islamic Studies.

Khan, M. S., \& Mirakhor, A. (1990). Islamic Banking: Experiences in the Islamic Republic of Iran and in Pakistan. Economic Development and Cultural Change, 38(2), 353-375.

Kuran, T. (1995). Islamic Economics and the Islamic Subeconomy. The Journal of Economic Perspectives, 9(4), 155-173.

Lewis, M., \& Algaoud, L. M. (2001). Islamic banking. Cheltenham, UK; Northampton, MA: Edward Elgar.

Munawar, I. (2007). A guide to Islamic finance. London: Haymarket House.

Nyazee, I. A. K. (1995). The concept of Riba and Islamic banking. Islamabad: Niazi Pub. House.

Saffari, S. (1995). Islamic Banking in Theory and Practice: The Experience of Iran. Centre for Middle Eastern Studies, . Harvard University Cambridge, MA.

Samad, A., Gardner, N. D., \& Cook, B. J. (2005). Islamic Banking and Finance in Theory and Practice: The Experience of Malaysia and Bahrain. The American journal of Islamic social sciences., 22(2), 69-86.

Schoon, N. (2009). Islamic banking and finance. London: Spiramus Press.

Siddiqi, M. N. (1983). Issues in Islamic banking: selected papers. Leicester, UK: Islamic Foundation.

Siddiqi, M. N. (2005). Riba, bank interest and the rationale of its prohibition. New Delhi: Markazi Maktaba Islami Publishers.

Siddiqi, M. N. (2007). Economics of Tawarruq, How its mafasid overwhelm the Masalih. Paper presented at the A Methodological issue in Sharî‘a-Compliant Finance, London School of Economics, London, UK.

Usmani, M. T. (2002). An introduction to Islamic finance. Hague; New York: Kluwer Law International.

Visser, H. (2009). Islamic finance principles and practice. Cheltenham, UK; Northampton, Massachusetts: Edward Elgar Publishing Limited.

Vogel, F. E., \& Hayes, S. L. (1998). Islamic law and finance: religion, risk, and return. Boston, Mass.: Kluwer Law International.

Yousef, T. M. (2004). The Murabaha Syndrome in Islamic Finance: Laws, Institutions and Politics. In C. M. Henry \& R. Wilson (Eds.), The politics of Islamic finance. Edinburgh: Edinburgh University Press. 